\title{
Soil wind erosion in ecological olive trees in the Tabernas desert (southeastern Spain): a wind tunnel experiment
}

\author{
Carlos Asensio $^{1}$, Francisco Javier Lozano ${ }^{1}$, Pedro Gallardo ${ }^{1}$, and Antonio Giménez ${ }^{2}$ \\ ${ }^{1}$ Departamento de Agronomía, CEIA3, Campus de Excelencia Internacional en Agroalimentación, \\ Universidad de Almería, Almería, Spain \\ ${ }^{2}$ Departamento de Ingeniería, Universidad de Almería, Almería, Spain \\ Correspondence to: Carlos Asensio (casensio@ual.es)
}

Received: 12 April 2016 - Published in Solid Earth Discuss.: 29 April 2016

Revised: 27 July 2016 - Accepted: 28 July 2016 - Published: 22 August 2016

\begin{abstract}
Wind erosion is a key component of the soil degradation processes. The purpose of this study is to find out the influence of material loss from wind on soil properties for different soil types and changes in soil properties in olive groves when they are tilled. The study area is located in the north of the Tabernas Desert, in the province of Almería, southeastern Spain. It is one of the driest areas in Europe, with a semiarid thermo-Mediterranean type of climate. We used a new wind tunnel model over three different soil types (olive-cropped Calcisol, Cambisol and Luvisol) and studied micro-plot losses and deposits detected by an integrated laser scanner. We also studied the image processing possibilities for examining the particles attached to collector plates located at the end of the tunnel to determine their characteristics and whether they were applicable to the setup. Samples collected in the traps at the end of the tunnel were analyzed. We paid special attention to the influence of organic carbon, carbonate and clay contents because of their special impact on soil crusting and the wind-erodible fraction. A principal components analysis (PCA) was carried out to find any relations on generated dust properties and the intensity and behavior of those relationships. Component 1 separated data with high $\mathrm{N}$ and $\mathrm{OC}$ contents from samples high in fine silt, $\mathrm{CO}_{3}=$ and available $\mathrm{K}$ content. Component 2 separated data with high coarse silt and clay contents from data with high fine sand content. Component 3 was an indicator of available $\mathrm{P}_{2} \mathrm{O}_{5}$ content. Analysis of variance (ANOVA) was carried out to analyze the effect of soil type and sampling height on different properties of trapped dust. Calculations based on tunnel data showed overestimation of erosion in soil types and calculation of the fraction of soil erodible by wind done
\end{abstract}

by other authors for Spanish soils. As the highest loss was found in Cambisols, mainly due to the effect on soil crusting and the wind-erodible fraction aggregation of $\mathrm{CaCO}_{3}$, a Stevia rebaudiana cover crop was planted between the rows in this soil type and this favored retention of particles in vegetation.

\section{Introduction}

Soil is a key component of the Earth system as it controls the hydrological, erosional, biological and geochemical cycles and also contributes services, goods and resources to humankind (Keesstra et al., 2012; Brevik et al., 2015; Smith et al., 2015). Soil degradation is related to soil compaction, loss of vegetation and organic matter and increase of soil erosion, either by water or wind (Novara et al., 2011; Prosdocimi et al., 2016; Arjmand Sajjadi and Mahmoodabadi, 2015). The study of these land degradation processes will contribute to appropriate restoration and rehabilitation and the understanding of soil genesis and related processes of soil degradation and formation. Wind erosion is a world-wide environmental concern (Houyou et al., 2014; Martínez-Graña et al., 2015) but some regions of the world are more affected due to their climatic conditions (Cerdà et al., 2010; Borrelli et al., 2016). In semiarid regions, where the distribution and intensity of precipitation are irregular, wind moves enormous amounts of soil, with the consequential ecological imbalance. Several authors (Liu et al., 2003; López et al., 2000; Li et al., 2004; Gao et al., 2015) have studied the relationships of wind erosion, wind speed, soil typology and vegetation, which affect 
the quality of soil by modifying the organic carbon (OC) content.

Leys et al. (2002) evaluated the wind erosion range based on the effect of dry aggregation levels and percentage of clay. Zobeck et al. (2013) observed a decrease in dry mechanical and aggregate stability and a progressive lost of organic matter under wind erosion processes. Beniston et al. (2015) discussed $\mathrm{P}$ losses driven by the transport of the mineral fraction, under different types of soil tillage and management. Kaiser et al. (2014) suggested that the stocks of stable C and $\mathrm{N}$ pools were not affected by the tillage intensity but were positively correlated with clay content, indicating a strong influence of site-specific mineral characteristics on the size of these pools.

Benlhabib et al. (2014) analyzed dryland Mediterranean cultivation systems, discussing and recommending sustainable cultivation technologies which showed a significantly positive effect on crop productivity, yield stability and environmental sustainability. Hevia et al. (2007) found that notill showed more large aggregates and fewer fine aggregates than traditional tillage. This was also indicated by Gao et al. (2015) and Wang et al. (2015) over soil-conserving tillage in Northern China. Gomesa et al. (2003) observed that soil erodibility by wind under traditional tillage was lower than in conservation tillage, since only a limited amount of material was available to wind erosion due mainly to crusting of the soil surface. Colazo and Buschiazzo (2010, 2015) confirmed that cultivation increased the erodible fraction (EF) of soil and reduced dry aggregate stability (DAS) in mediumtextured soils by causing a weakening of the soil structure due to loss of OC and breakup of aggregates. In fine-textured soils, the formation of large resistant aggregates by tilling causes EF and DAS to be more alike than under no-till conditions. Rawlins et al. (2015) suggested that soil quality, measured by critical soil physical properties, may decline if the OC concentration is below a critical threshold. Hagen et al. (2010) observed that tilling ridges are effective for trapping aggregates transported by saltation but do not usually reduce erosion rates in soils where aggregates transported in suspension predominate.

Feras et al. (2008) demonstrated in a wind tunnel study that sediment trap efficiency depended mainly on particle size and wind speed. Traps placed at different heights can measure vertical sediment flow (Basaran et al., 2011).

Expansion and intensification of olive tree cultivation in Andalusia, especially in the late 18th century, accelerated erosion processes. The introduction of cover crops in the region after application of the standards derived from the EU Common Agricultural Policy requires the need for additional management investment (Gómez et al., 2014). In fact, cultivation of Stevia rebaudiana down the center between rows of olive trees is under study in our experimental area.

Vegetation protects soil from wind erosion because it reduces the wind speed and soil erodibility and traps more eroded material (Touré et al., 2011; Leenders et al., 2011;
Lozano el al., 2013; Asensio et al., 2015). Udo and Takewaka (2007), in their wind tunnel experiments, concluded that, in addition to density, the height and flexibility of vegetation are essential in determining the effectiveness in decreasing mass transport by wind. Youssef et al. (2012) suggested that the pattern of vegetation in parallel rows to the predominant wind direction lowers total mass transport.

In this paper, our objectives are (1) to study the influence of material loss on soil properties, (2) to compare the differences in soil loss due to the soil type and (3) to observe the changes in generated dust properties in olive-cropped soils from a semiarid area in southeastern Spain.

\section{Material and methods}

\subsection{Study area}

The study area is located in the north of the Tabernas Desert, about $10 \mathrm{~km}$ NE of the Tabernas town $\left(37^{\circ} 03^{\prime} \mathrm{N}, 22^{\circ} 23^{\prime} \mathrm{W}\right.$; 400 m a.s.l.) in Almería Province, southeastern Spain, which is in the Sorbas-Tabernas Basin, south of the Sierra de Los Filabres and partly surrounded by the Betic Mountain Range. The climate is semiarid thermo-Mediterranean, with a mean annual temperature of $17.8^{\circ} \mathrm{C}$. It is one of the driest areas in Europe, with a mean annual precipitation of $283 \mathrm{~mm}$ according to the Tabernas meteorological station records for the last 15 years. Lithological material is predominantly sedimentary, identified as a series of marls in contact with Miocene evaporites. Most soil is covered by Mediterranean shrubs, alternating with patches of annual grasses, biological crusts and bare surfaces (Cantón et al., 2011). The study area is on the property of the "Oro del Desierto" olive oil company, which has around 25000 olive trees of different ages scattered on about 100 ha surrounded by scrubland and other ecological crops, such as candyleaf, almonds and grapes. We concentrated on 4-year-old picual olive trees that were drip irrigated. According to IUSS Working Group WRB (2015), soils are mainly Calcisols (CL), Cambisols (CM) and Luvisols (LV). Texture is silty clay loam to loamy with 37 to $48 \%$ gravel fragments and a weak, coarse subangular blocky to strong, medium angular blocky structure (FAO, 2006).

\subsection{Data acquisition and experimental design}

Soil parameters of the different soil types were analyzed before making applications of artificial wind in the tunnel. To analyze the soil volume lost from wind erosion and its effect on the surface microtopography, we tested both crusted and recently tilled soil. The crusted soils were strongly protected from wind erosion, while soils were highly susceptible to it immediately after tilling. After tilling, the surface crust was re-established within 10 to 12 days, reacquiring extra protection to the wind.

Simulations were performed in May 2013 in three plots for each soil type with olive trees, with $7 \times 5 \mathrm{~m}$ tree spacing, 
which were only tilled once a year and where the aisles between the rows were very close to the predominant wind direction (there was about a $5^{\circ}$ offset in Calcisols). The slopes and lengths of fields of the three experimental plots were $2 \%$ and $143 \mathrm{~m}$ on CL, $0 \%$ and $95 \mathrm{~m}$ on CM and $0 \%$ and $152 \mathrm{~m}$ on LV.

Our reference for weather records was the Tabernas Meteorological Station (located about $2 \mathrm{~km}$ away from the study area), one of the network of automatic stations belonging to the Andalusian Institute for Agriculture, Fishing, Research and Education (IFAPA).

\subsection{Wind tunnel}

To monitor wind intensity, as well as direction and shear intensity, we worked with a wind tunnel with laminar and turbulent flow similar to real wind conditions, in which the material transported was collected in traps for study. Our tunnel has two parts, as shown in Fig. 1, each one with different functions. Part 1 includes a power generator, which provides the energy necessary for the industrial fan which is the first component. The fan blows air into a folding tube structure ( $2 \mathrm{~m}$ long), providing an air flow which combines laminar and turbulent flows as it passes through an intermediate honeycomb structure. Part 2 includes the tunnel itself, which consists of three compartments $(0.8 \times 0.8 \times 0.8 \mathrm{~m}$ each one $)$ in a telescopic structure. (i) The first compartment has a metal sheet completely covering the ground to keep the wind from affecting this area; (ii) the second compartment is the study area itself $(0.8 \times 0.8 \mathrm{~m})$, where wind erosion is actually quantified. This area is equipped with a PCE-424 hot wire anemometer with $0.1 \mathrm{~m} \mathrm{~s}^{-1}$ resolution, with which wind speed is monitored. There is also a NextEngine Desktop 3D laser scanner, which is used to find the volume of eroded soil and alterations in the microrelief of the soil. The scanner has an indispensable lifting system which acts as a support structure and enables it to be set at the desired height. (iii) A liquid latex (Latepren ${ }^{\circledR} \mathrm{Rx}-505$ ) coating was applied to the soil surface in the third compartment to fix particles so they would not move around during blowing and mix in with the particles in the study zone. This way the natural roughness of the ground was maintained. The latex coating is spread with a bulb shape from outside the third tunnel compartment to avoid return of external particles due to edge turbulence.

At the end of the tunnel, particles are attached to vertical adhesive plates placed at different heights $(0,15,40$ and $70 \mathrm{~cm}$ ), which are later analyzed using a camera.

Particle traps (Fryrear BSNE, adapted for a fixed wind direction), located at the same heights as the adhesive plates (Asensio et al., 2015), retain the dust that is later analyzed to quantify the loss; the $0 \mathrm{~cm}$ one was partially buried in order to locate the window at surface level.

The duration of each wind tunnel experiment was $10 \mathrm{~min}$ at a wind speed of $7.6 \mathrm{~m} \mathrm{~s}^{-1}, 70 \mathrm{~cm}$ height, according to Fister and Ries (2009). The wind speed value corresponds to the

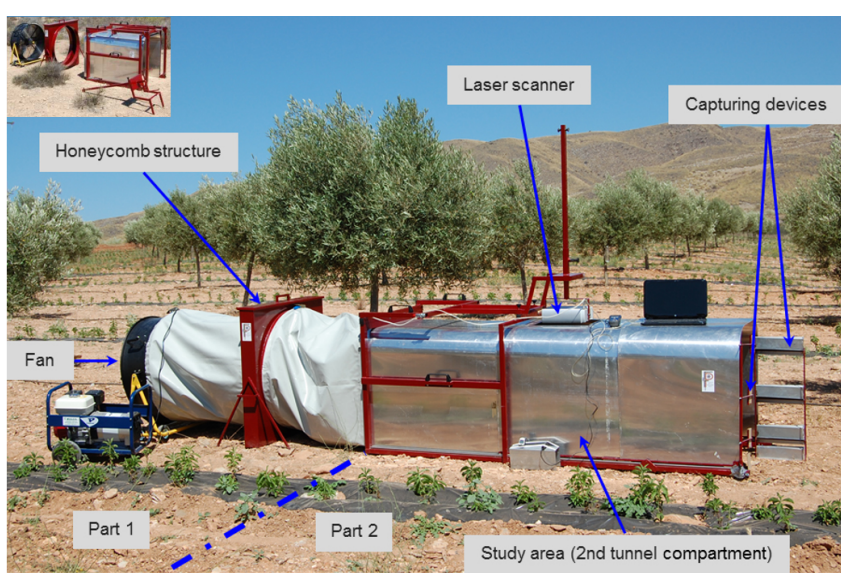

Figure 1. Details of the wind tunnel device.

maximum daily average wind speed (last 15 years) registered at $2 \mathrm{~m}$ height by Tabernas Station. Flow simulation software, according to $15 \mathrm{~cm}$ tunnel rounding radius, shows wind profile homogeneity from $70 \mathrm{~cm}$ height to the central part of the ground study area (second compartment) at cross section.

In each case, the soil surface was scanned twice, before and after simulation with the wind tunnel. Scans were carried out under conditions of natural dryness by a NextEngine 3-D laser scanner placed at a height of $44 \mathrm{~cm}$. This scanner has shown its applicability in acquiring microreliefs of agricultural soils (Aguilar et al., 2009) in high-precision field work (high definition mode and MACRO) with a sample size large enough to represent the plot in great detail. This provides a $120 \mathrm{~cm}^{2}$ scan area with a 400 ppi capture density and nominal precision of $0.127 \mathrm{~mm}$. Based on two point clouds found for each plot (before and after wind simulation), two digital terrain models (DTMs) with a $0.1 \times 0.1 \mathrm{~cm}$ resolution were generated. The volume of eroded soil was estimated as the difference in volume between both DTMs. Once the volume of eroded soil was known, we estimated the amount of soil lost using the bulk density of each soil.

After making applications of artificial wind in the tunnel, we analyzed changes in surface microtopography from both crusted and recently tilled soils. The results of the scans done in the wind tunnel only take the loss model (no deposit model) into account. Deposits would have to be considered along with the loss model for the erosion balance to be more moderate.

To find out how wind erosion modifies surface microtopography, the point cloud from each scan was used to calculate random roughness (RR) in each case, before and after simulation. RR is defined as the standard deviation from the points within the plot after eliminating the slope effect. However, in natural areas with a complex topography or on hillsides with high variability (changes in both flat curvature and profile), the elimination of slope does not eliminate the effects of changes in height caused by roughness factors, 
such as mounds, curvature or higher-order variations in surface, so the RR index tends to overestimate surface roughness in experimental plots. Therefore, the local $R R$ index $\left(R_{L}\right)$ estimation method was applied (Rodríguez-Caballero et al., 2012) using Eq. (1):

$\mathrm{RR}_{\mathrm{L}}=\sqrt{\sum_{i=1}^{i=\mathrm{Nw}} \frac{(\mathrm{Zw}-\mu w)^{2}}{(1-\mathrm{Nw})}}$

where $\mathrm{Nw}$ is the number of points in window $w, \mathrm{Zw}$ is the height of each point after eliminating the slope effect and $\mu w$ is the mean height in window $w$.

The adhesive plates were analyzed using a machine vision camera (JAI-CM080). This monochrome progressive scan camera with a $1024 \times 768$ pixel resolution is connected to a computer. During image processing with the "ImageJ" program, the number of particles present in each image can be counted, and the mean size of particles, presence of aggregates or a color histogram of the image can be found.

The possibilities for image processing for detailed examination of particles adhering to the plates were studied. In a first approach, to determine the characteristics and applicability to the setup, a series of images of reference samples was taken to demonstrate system capabilities of (i) colorimetry studies, quantitative study of the color of adhered particles, changing the color model and using the $\mathrm{H}$ component in the HSV model; (ii) measurement on image of adhered particles; (iii) particle count; and (iv) roughness analysis of isolated particles

\subsection{Sampling and analytical determinations}

Soil samples were collected from the $0-3 \mathrm{~cm}$ soil layer. We therefore concentrated on recently tilled soils, from which three repetitions of each soil type were evaluated. When using aggregate stability to assess soil erodibility, samples are usually collected from the plough layer, while soil erosion occurs at the soil surface. Hence, the potential changes in erodibility caused by crusting are ignored (Algayer et al., 2014). Using soil material immediately below the crust layer would have led to greatly overestimated erodibility.

Ground and collected samples were dried, crushed and passed through a $2 \mathrm{~mm}$ sieve to eliminate large fragments. Surface stoniness was determined in weigh. For both collected soil and trapped particle samples, particle size distribution was assessed by dry sieving and the Robinson pipette method after eliminating organic matter with $\mathrm{H}_{2} \mathrm{O}_{2}$ (30\%) and dispersion by agitation with sodium hexametaphosphate $(10 \%)$. The sand fraction was separated by wet sieving, dried in an oven and later fractionated by dry sieving. Obtained granulometric fractions were very coarse sand $(2000-1000 \mu \mathrm{m})$, coarse sand $(1000-500 \mu \mathrm{m})$, medium sand $(500-250 \mu \mathrm{m})$, fine sand $(250-100 \mu \mathrm{m})$, very fine sand $(100-50 \mu \mathrm{m})$, coarse silt $(50-20 \mu \mathrm{m})$, fine silt $(20-2 \mu \mathrm{m})$ and clay $(<2 \mu \mathrm{m})$. The OC content was determined using the

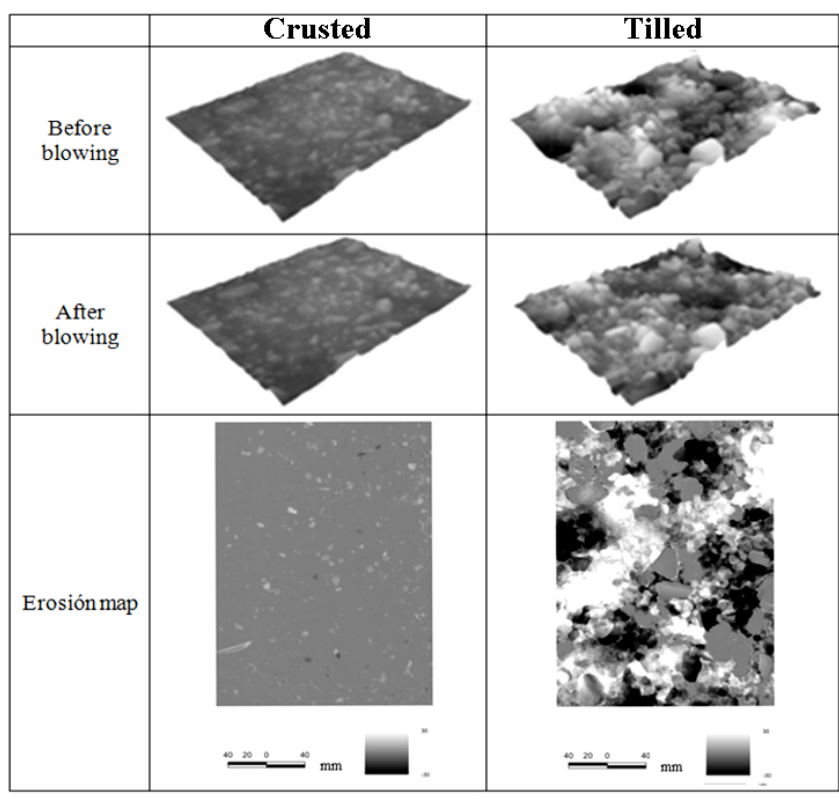

Figure 2. Digital terrain models and erosion maps for a Cambisol.

Walkley-Black wet digestion method. Total nitrogen content was calculated from $\mathrm{NH}_{3}$ volumetry after Kjeldahl digestion. Available soil phosphate $\left(\mathrm{P}_{2} \mathrm{O}_{5}\right)$ was calculated by photocolorimetry. Available soil potassium was calculated by flame photometry. To determine bulk density (BD), $100 \mathrm{~cm}^{3}$ cylinders were used to refer to sample dry weight by cylinder volume.

\subsection{Statistical analysis}

Data on soil characteristics acquired were examined for any changes or differences. Previously to further analyses, the normal distribution of data and homogeneity of variances was checked using the Shapiro-Wilk and Levene's tests, respectively. A principal components analysis (PCA, with Varimax rotation) was carried out to estimate any relationships of generated dust properties and the intensity and behavior of those relationships. Then an analysis of variance (ANOVA) was done to analyze the effect of soil type on $\mathrm{OC}$ and $\mathrm{CO}_{3}^{=}$ contents and another ANOVA was done to analyze the effect of height on clay content. When the ANOVA null hypothesis was rejected, pairwise comparisons were assessed using the least significant difference test. The level of significance was 0.05 in all tests. All statistical analyses were carried out with SPSS v20 (IBM Corp., 2011).

\section{Results}

At the study area, mean soil characteristics before artificial wind recorded for Calcisols, Cambisols and Luvisols $\left(\mathrm{CL}_{0}\right.$, $\mathrm{CM}_{0}$ and $\mathrm{LV}_{0}$ ) are shown in Table 1 . Three replicates were taken of each soil type. 
Table 1. Initial soil characteristics for Calcisols $\left(\mathrm{CL}_{0}\right)$, Cambisols $\left(\mathrm{CM}_{0}\right)$ and Luvisols $\left(\mathrm{LV}_{0}\right)$ tested (OC: organic carbon; $\mathrm{AWC:} \mathrm{available}$ water content).

\begin{tabular}{|c|c|c|c|c|c|c|c|c|}
\hline Soil type & $\%$ Very coarse sand & $\%$ Coarse sand & $\%$ Medium sand & $\%$ Fine sand & $\%$ Very fine sand & $\%$ Coarse silt & $\%$ Fine silt & $\%$ Clay \\
\hline $\mathrm{CL}_{0}$ & $0.0 \pm 0.0$ & $5.2 \pm 0.2$ & $5.5 \pm 0.3$ & $1.9 \pm 0.1$ & $10.7 \pm 0.8$ & $34.7 \pm 1.2$ & $18.3 \pm 0.8$ & $23.7 \pm 1.8$ \\
\hline $\mathrm{CM}_{0}$ & $0.2 \pm 0.0$ & $8.1 \pm 0.4$ & $7.6 \pm 0.2$ & $8.8 \pm 0.4$ & $20.2 \pm 0.7$ & $28.4 \pm 0.9$ & $7.9 \pm 0.5$ & $18.8 \pm 0.7$ \\
\hline $\mathrm{LV}_{0}$ & $0.3 \pm 0.1$ & $5.3 \pm 0.1$ & $6.1 \pm 0.4$ & $8.9 \pm 0.6$ & $25.9 \pm 1.1$ & $26.8 \pm 1.6$ & $6.3 \pm 0.2$ & $20.4 \pm 1.0$ \\
\hline Soil type & $\% \mathrm{OC}$ & $\% \mathrm{~N}$ & $\begin{array}{c}\text { Available } \mathrm{P}_{2} \mathrm{O}_{5} \\
\left(\mathrm{mg} 100 \mathrm{~g}^{-1}\right)\end{array}$ & $\begin{array}{l}\text { Available K } \\
\left(\mathrm{mg} 100 \mathrm{~g}^{-1}\right)\end{array}$ & $\% \mathrm{CO}_{3}^{=}$ & $\begin{array}{c}\text { E.C. } \\
\left(\mathrm{dS} \mathrm{m}^{-1}\right)\end{array}$ & & \\
\hline $\mathrm{CL}_{0}$ & $1.04 \pm 0.07$ & $0.036 \pm 0.005$ & $4 \pm 1$ & $28 \pm 4$ & $36 \pm 3$ & $5.55 \pm 0.24$ & & \\
\hline \multirow[t]{2}{*}{ Soil type } & \multicolumn{2}{|l|}{$\mathrm{pH}$} & \multicolumn{2}{|c|}{$\mathrm{pF}$} & & & & \\
\hline & $\mathrm{H}_{2} \mathrm{O}$ & $\mathrm{KCl}$ & $\% \mathrm{H} 33 \mathrm{kPa}$ & $\% \mathrm{H} 1500 \mathrm{kPa}$ & $(\mathrm{mm})$ & $\left(\mathrm{g} \mathrm{cm}^{-3}\right)$ & & \\
\hline $\mathrm{CL}_{0}$ & $7.78 \pm 0.07$ & $7.57 \pm 0.09$ & $13.068 \pm 0.114$ & $6.966 \pm 0.084$ & $11.1 \pm 0.2$ & $1.40 \pm 0.02$ & & \\
\hline
\end{tabular}

Data are mean \pm standard deviation before applying wind in three replicates for each soil type.

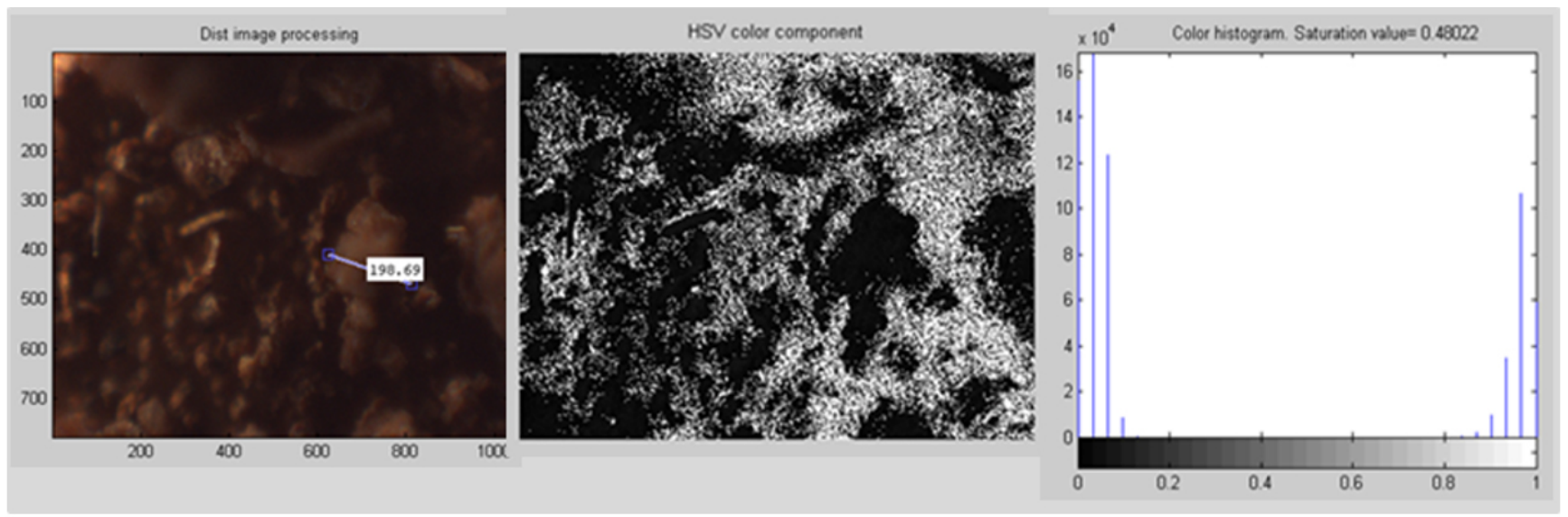

Figure 3. Image of a Luvisol sample, $0 \mathrm{~cm}$ height, and pre-processing.

Surface stoniness of these soils is high and the average gravel for the different typologies is $37 \pm 7 \%$ in $\mathrm{CL}$, $48 \pm 8 \%$ in $\mathrm{CM}$ and $43 \pm 5 \%$ in LV.

Wind experiments caused different intensities of soil lowering, soil loss and roughness in the studied types of soils (Table 2).

As an example of the results found by scanning, the digital terrain models and erosion maps for a sample from the Cambisol plot are shown in Fig. 2. The variations in RR are conditioned by the balance of material lost and deposited.

Some of the results of the image processing plate study are shown below (Fig. 3). Calcisols have fewer granulometric fractions susceptible to wind erosion. The three typologies have a clear contrast in color that is conditioned by their clay content and the presence of iron oxides. In Calcisols, the aggregating effect of $\mathrm{CaCO}_{3}$ may be seen even with the naked eye.
Figure 3 shows large-sized particles, plant residue and, in the color analysis, two groups of materials with different colorimetry.

The samples collected in the traps at the end of the tunnel were also analyzed. A PCA of the results was performed using the $\mathbf{R}$ correlation matrix. The variables included in the PCA were fine sand, very fine sand, coarse silt, fine silt, clay, OC, $\mathrm{N}$, available $\mathrm{P}_{2} \mathrm{O}_{5}$, available $\mathrm{K}$ and $\mathrm{CO}_{3}^{=}$. Only the first three components were considered, as they explained $81.01 \%$ of variance.

Figure 4a shows the correlation coefficients on the plane of components 1 and 2. From this figure, it is obvious that the $\%$ fine silt, $\% \mathrm{CO}_{3}^{=}$and available $\mathrm{K}$ variables are clearly negatively associated with component 1 while $\% \mathrm{~N}$ and $\%$ OC are associated positively with component 1 . Thus component 1 separates data with high $\mathrm{N}$ and $\mathrm{OC}$ contents from samples high in fine silt, $\mathrm{CO}_{3}^{=}$and available $\mathrm{K}$ content. Component 2 

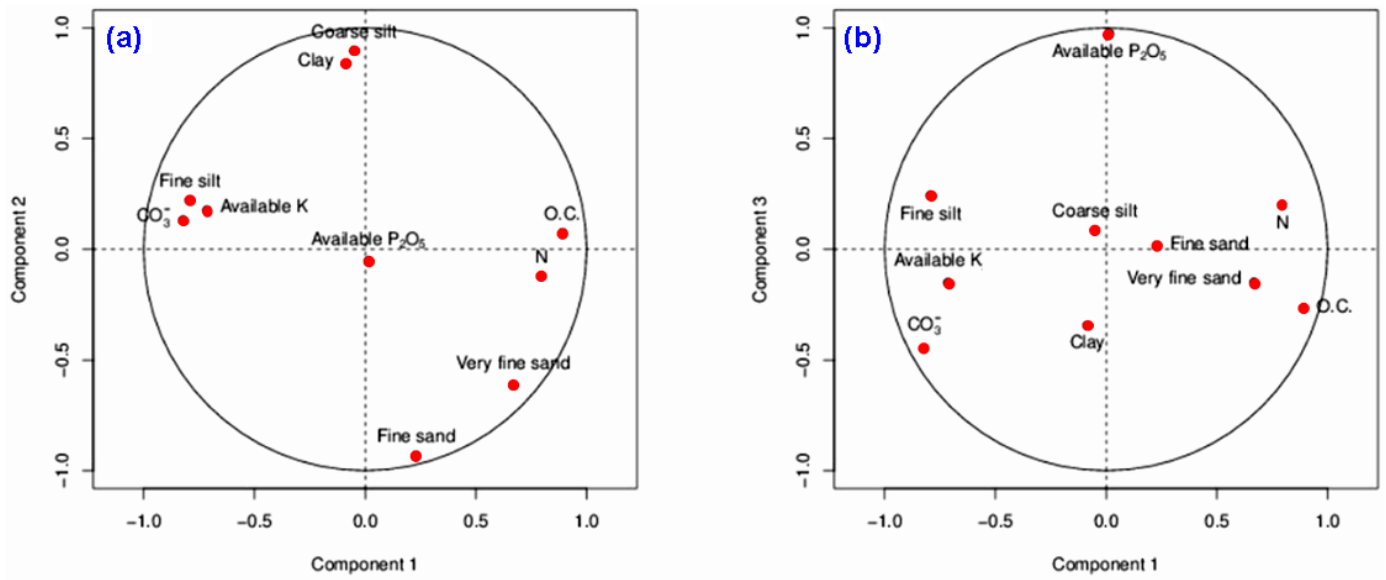

Figure 4. Plot of the correlation coefficients within a unit circle on the plane of components 1 and 2 (a) and components 1 and 3 (b).
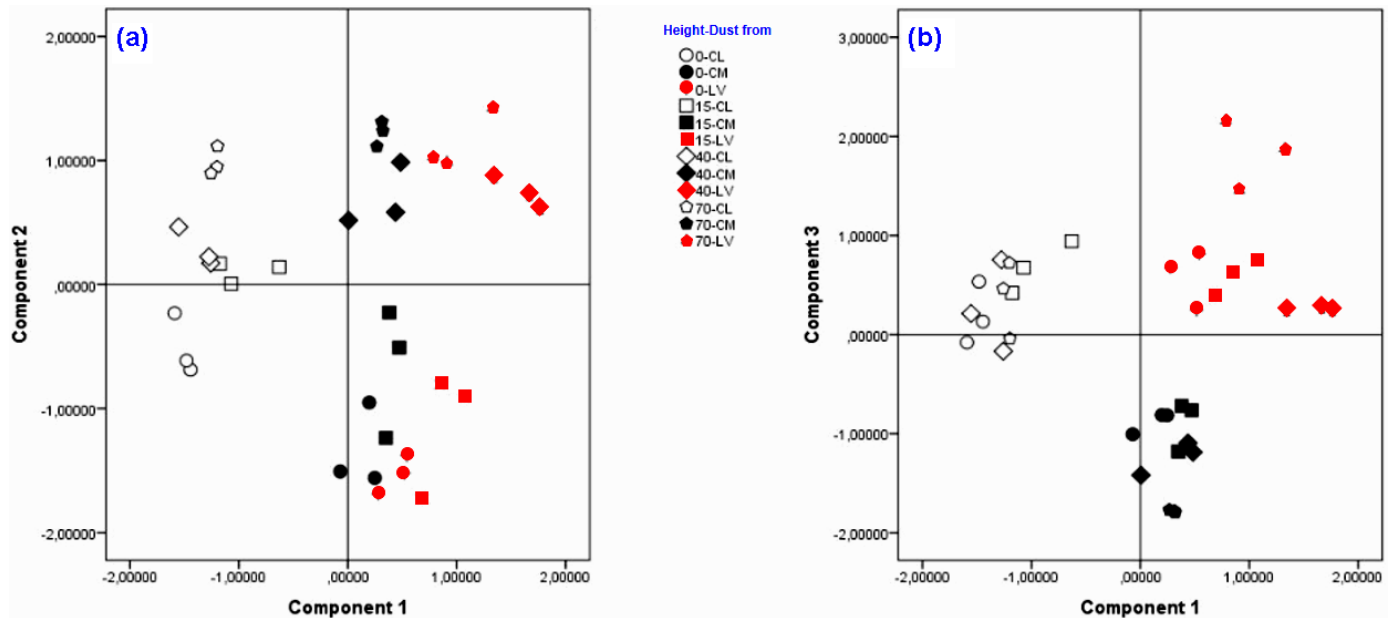

Figure 5. Scatter plot of the height-dust from Calcisols (CL), Cambisols (CM) and Luvisols (LV) categories for the components 1 and 2 matrix (a) and the components 1 and 3 matrix (b).

Table 2. Average lowering of the soil surface, soil loss and random roughness $\left(\mathrm{RR}_{\mathrm{L}}\right)$ before and after wind experiments in different soil types.

\begin{tabular}{llcrcc}
\hline Soil type & Surface & $\begin{array}{c}\text { Lowering of the } \\
\text { surface }(\mathrm{mm})\end{array}$ & $\begin{array}{r}\text { Soil loss } \\
\left(\mathrm{g} \mathrm{m}^{-2}\right)\end{array}$ & $\begin{array}{c}\mathrm{RR}_{\mathrm{L}} \\
\text { (before) }\end{array}$ & $\begin{array}{c}\mathrm{RR}_{\mathrm{L}} \\
(\text { after})\end{array}$ \\
\hline Calcisols & Crusted & $0.54 \pm 0.06$ & $756 \pm 84$ & $2.60 \pm 0.33$ & $2.36 \pm 0.38$ \\
& Tilled & $1.06 \pm 0.15$ & $1484 \pm 210$ & $7.81 \pm 0.84$ & $7.28 \pm 0.78$ \\
\hline Cambisols & Crusted & $0.25 \pm 0.04$ & $338 \pm 54$ & $3.54 \pm 0.41$ & $3.51 \pm 0.44$ \\
& Tilled & $1.83 \pm 0.21$ & $2471 \pm 284$ & $7.47 \pm 0.91$ & $6.51 \pm 0.89$ \\
\hline Luvisols & Crusted & $0.09 \pm 0.00$ & $110 \pm 0$ & $2.45 \pm 0.32$ & $2.43 \pm 0.40$ \\
& Tilled & $1.39 \pm 0.18$ & $1696 \pm 220$ & $7.52 \pm 0.85$ & $6.18 \pm 0.72$ \\
\hline
\end{tabular}

Data are means \pm standard deviation 
Table 3. Summary table for the ANOVAs of $\% \mathrm{OC}, \% \mathrm{CO}_{3}^{\bar{y}}$ and $\%$ clay.

\begin{tabular}{|c|c|c|c|c|c|}
\hline Source & $\begin{array}{l}\text { Degrees } \\
\text { of freedom }\end{array}$ & Sum of squares & $\begin{array}{r}\text { Mean } \\
\text { square }\end{array}$ & $F$ ratio & $P$ \\
\hline \multicolumn{6}{|c|}{$\% \mathrm{OC}$} \\
\hline Soil & 2 & 3.914 & 1.957 & 85.036 & 0.000 \\
\hline Residuals & 33 & 0.760 & 0.023 & & \\
\hline Total & 35 & 4.674 & & & \\
\hline \multicolumn{6}{|c|}{$\% \mathrm{CO}_{3}^{=}$} \\
\hline Soil & 2 & 4167.722 & 2083.861 & 143.116 & 0.000 \\
\hline Residuals & 33 & 480.500 & 14.561 & & \\
\hline Total & 35 & 4648.222 & & & \\
\hline \multicolumn{6}{|c|}{$\%$ Clay } \\
\hline Height & 3 & 167.252 & 55.751 & 18.785 & 0.000 \\
\hline Residuals & 32 & 94.971 & 2.968 & & \\
\hline Total & 35 & 262.223 & & & \\
\hline
\end{tabular}

is negatively associated with fine sand and positively associated with $\%$ coarse silt and \% clay. Component 2 separates data with high coarse silt and clay content from data with high fine sand content.

Figure $4 \mathrm{~b}$ shows the correlation coefficients on the plane of components 1 and 3, where it may be observed that component 3 is positively associated with available $\mathrm{P}_{2} \mathrm{O}_{5}$. Therefore component 3 is an indicator of available $\mathrm{P}_{2} \mathrm{O}_{5}$ content.

Figure 5 shows sample clustering around the three main components. Component 1 is strongly related to the soil group (Fig. 5a). Thus, dust samples from CL show the highest available $\mathrm{K}$ content and dust samples from LV show higher $\mathrm{N}$ content.

Furthermore, component 2 is related to the sampling height and separates 0 and $15 \mathrm{~cm}$ from 40 and $70 \mathrm{~cm}$. Therefore, the lower heights are associated with higher content in fine sand while higher heights are associated with more content in coarse silt and clay.

Component 3 separates soil groups $\mathrm{CL}$ and LV from CM, suggesting that available $\mathrm{P}_{2} \mathrm{O}_{5}$ content is the major difference (Fig. 5b).

Special attention should be paid to PCA results for OC, $\mathrm{CO}_{3}=$ and clay contents because of their special impact on soil crusting and the wind-erodible fraction. Variables $\mathrm{OC}$ and $\mathrm{CO}_{3}^{=}$were associated with component 1 , which is strongly related to soil type. So we tested the effects of soil type on $\mathrm{OC}$ and $\mathrm{CO}_{3}^{=}$contents with ANOVA. Furthermore, the clay variable was associated with component 2 , which was related to the height, and therefore we tested the effect of height on clay content. We did not need to apply transformations to satisfy the requirements of residual normality and variance homogeneity.

The ANOVA results for collected dust samples from different soil types (Table 3) applied to $\mathrm{OC} \%$ and $\mathrm{CO}_{3}^{=} \%$ show significant differences for soil provenance in two variables. When its effect was found to be significant in the
Table 4. Fisher's least significant difference (LSD) post hoc analysis for \% $\mathrm{OC}, \% \mathrm{CO}_{3}^{=}$and \% clay in Calcisols (CL), Cambisols (CM) and Luvisols (LV) samples.

\begin{tabular}{lrcc}
\hline Source & Mean difference & LSD & $P$ Value \\
\hline \multicolumn{4}{c}{$\%$ OC } \\
\hline Soils & & \\
\hline CL vs. CM & -0.71167 & 0.1259 & 0.000 \\
CL vs. LV & -0.68667 & 0.1259 & 0.000 \\
CM vs. LV & 0.02500 & 0.1259 & 0.689 \\
\hline \multicolumn{5}{c}{$\% \mathrm{CO}_{3}^{=}$} \\
\hline Soils & 6.083 & 3.1694 & 0.000 \\
\hline CL vs. CM & 25.250 & 3.1694 & 0.000 \\
CL vs. LV & 19.167 & 3.1694 & 0.000 \\
CM vs. LV & $\%$ Clay & \\
\hline & & & \\
\hline Height & 0.0333 & 1.6543 & 0.968 \\
\hline 0 vs. 15 & -2.0000 & 1.6543 & 0.019 \\
\hline 40 vs. 70 & &
\end{tabular}

ANOVAs, and because none were considered the reference soil, we performed pairwise comparisons of the three soils. These were assessed using the least significant difference test (LSD, $p \leq 0.05$ ). Samples with the highest OC content were from LV but with no significant difference from CM (Table 4). CL had significantly lower OC content than the other two soil types. $\mathrm{CO}_{3}=$ contents were significantly different in the three soil types and $\mathrm{CL}$ had the highest $\% \mathrm{CO}_{3}^{=}$, while $\mathrm{LV}$ had the lowest.

The ANOVA results for height (Table 3) applied to clay content shows significant differences too. From Table 4, the difference between heights of 0 to 15 and 40 to 70 is referred in Eq. (2):

$L=\frac{1}{2}(23.844+23.811)-\frac{1}{2}(26.900+28.900)=-4.0725$.

As $t$ is $7.0912\left(t=4.0725 / 0.5743, p=4.811713 \times 10^{-8}\right)$, the difference between the heights of $0-15$ and $40-70$ is highly significant.

We were also interested in the comparison between heights of 0 and $15 \mathrm{~cm}$ and between 40 and $70 \mathrm{~cm}$. The difference between 0 and $15 \mathrm{~cm}$ is clearly not significant (Table 4), whereas the difference between 40 and 70 is significant, and the highest content of clay was at a height of $70 \mathrm{~cm}$.

\section{Discussion}

Soil erosion is currently a major cause of land degradation and relevant at the European and global scales. Therefore 
more studies are needed to improve current models and integrate plot and regional studies to assist decision making (Panagos et al., 2012, 2014; Borrelli et al., 2015).

As suggested by Lozano et al. (2013) and Asensio et al. (2015), bulk density is doubly influenced; on one hand it tends to be reduced by the effect of organic enrichment, but on the other hand it is increased by the accumulation of fine materials. This has great influence on physical soil crusting. Organic matter often combines with fine soil particles and Zhao et al. (2009) found a correlation coefficient between clay and organic matter content of 0.95 .

In semiarid environments, the availability of phosphates for plants is conditioned by neighboring plants and seasonal dynamics. Zhang et al. (2014) observed damages by windblown sand and Zhao et al. (2007) showed that the effect of small deposits of sand on soil properties and performance of vegetation were not significant, although the soil temperature tended to rise with increasing thickness of deposits, which could affect the decomposition rates of organic matter.

According to PCA, component 1 separates data with high OC contents from high $\mathrm{CO}_{3}^{=}$content and component 3 is an indicator of available $\mathrm{P}_{2} \mathrm{O}_{5}$ content, being able to establish differences on soil groups. component 1 separates the three groups of soil, and samples belonging to the LV group show high content in OC. Component 2 is related to the sampling height and shows how higher heights are associated with higher content in clay. ANOVA shows significant differences for CM and LV in front of CL in OC content. We also found significant differences in clay content for heights of $40-70 \mathrm{~cm}$.

It is well known that the wind velocity threshold for particle detachment increases as the size is increases. We did not take into account aggregate size for captured samples in traps because these were crushed and passed through a $2 \mathrm{~mm}$ sieve for chemical analyzing. The soil EF by wind is a key parameter for estimating soil susceptibility to wind erosion. Fryrear et al. (1994) proposed a multiple regression equation for calculating EF which considers the organic matter, sand, silt, clay and calcium carbonate contents as predictive variables. In fact, it has been included in prediction models such as the current Revised Wind Erosion Equation (RWEQ). Calculation of the EF in Spanish soils is problematic due to their high content in $\mathrm{CaCO}_{3}$ (López et al., 2007), so the equation proposed is $\mathrm{EF}=4.77+7.43 \mathrm{sand} /$ clay $+27.6 /$ organic matter. Average EF calculated this way for our soils shows a slightly higher result in Cambisols (31\%, compared to $27 \%$ in Calcisols and Luvisols).

Making a comparison for crusted and tilled soil types on the average soil loss, the intensity of wind erosion in tilled CLs was more than 6 and 14 times higher than in CMs and LVs, respectively. However, this is taking into account only a loss model, without the deposition one.

Image analysis is a useful tool enabling submillimetric particles to be counted and their size, shape and color to be analyzed. This could lead to the creation of a database of soils with objectively measurable visual characteristics in the midterm.

As the highest loss was found in CMs, a candyleaf cover crop has been planted between the rows in this soil type (Fig. 1). Candyleaf cultivation can offer up to three crops a year, which is done manually for a leaf that, after drying, is crushed. This crop favored retention of particles in vegetation in the study area.

\section{Conclusions}

Tilled soils in olive groves show a direct relationship between the differences in OC and clay content after wind tunnel experiments. CMs are more eroded than CLs and LVs, mainly due to the effect on soil crusting and the wind-erodible fraction aggregation of $\mathrm{CaCO}_{3}$ in CLs and clay in LVs.

The wind tunnel experiments led to overestimation of differences in soil type loss compared to other EF evaluation methods. We could suggest that higher-precision data have been found with this new wind tunnel than found with any other tunnel designed to date due to high resolution of the devices used, such as laser scanner and particle imaging.

Where wind erosion is higher, it is recommended that cover crops be planted between the rows of olive trees.

Acknowledgements. The authors are grateful to S. Martínez (Department of Mathematics, University of Almería) for advice and comments on a previous version of this manuscript and J. A. Torres (Department of Computing, University of Almería) for help with image analysis. Thanks also to Deborah Fuldauer for the English language revision. This study was funded by the Andalusia Regional Government (RNM 3614 grant) and European Union ERDF funds.

Edited by: A. Jordán

Reviewed by: three anonymous referees

\section{References}

Aguilar, M. A., Aguilar, F., and Negreiros, J.: Off-the-shelf scanning and close-range digital photogrammetry for measuring agricultural soils microrelief, Biosystem Engineering, 103, 504-517, doi:10.1016/j.biosystemseng.2009.02.010, 2009.

Algayer, B., Wang, B., Bourennane, H., Zheng, F., Duval, O., Li, G., Le Bissonnais, Y., and Darboux, F.: Aggregate stability of a crusted soil: differences between crust and sub-crust material, and consequences for interrill erodibility assessment. An example from the Loess Plateau of China, Eur. J. Soil Sci., 65, 325335, doi:10.1111/ejss.12134, 2014.

Arjmand Sajjadi, S., and Mahmoodabadi, M.: Aggregate breakdown and surface seal development influenced by rain intensity, slope gradient and soil particle size, Solid Earth, 6, 311-321, doi:10.5194/se-6-311-2015, 2015.

Asensio, C., Lozano, F. J., Ortega, E., and Kikvidze, Z.: Study on the effectiveness of an agricultural Technique based on aeolian 
deposition, in a semiarid environment, Environ. Eng. Manag. J., 14, 1143-1150, 2015.

Basaran, M., Erpul, G., Uzun, O., and Gabriels, D.: Comparative efficiency testing for a newly designed cyclone type sediment trap for wind erosion measurements, Geomorphology, 130, 343351, doi:10.1016/j.geomorph.2011.04.016, 2011.

Beniston, J. W., Shipitalo, M. J., Lal, R., Dayton, E. A., Hopkins, D. W., Jones, F., Joynes, A., and Dungait, J. A. J.: Carbon and macronutrient losses during accelerated erosion under different tillage and residue management, Eur. J. Soil Sci., 66, 218-225, doi:10.1111/ejss.12205, 2015.

Benlhabib, O., Yazar, A., Qadir, M., Lourenço, E., and Jacobsen, S. E.: How Can We Improve Mediterranean Cropping Systems?, J. Agron. Crop Sci., 200, 325-332, 2014.

Borrelli, P., Panagos, P., and Montanarella, L.: New insights into the geography and modelling of wind erosion in the European agricultural land. Application of a spatially explicit indicator of land susceptibility to wind erosion, Sustainability, 7, 8823-8836, doi:10.3390/su7078823, 2015.

Borrelli, P., Panagos, P., Ballabio, C., Lugato, E., Weynantgs, M., and Montanarella, L.: Towards a Pan-European assessment of land susceptibility to wind erosion, Land Degrad. Dev., 27, 1093-1105, doi:10.1002/ldr.2318, 2016.

Brevik, E. C., Cerdà, A., Mataix-Solera, J., Pereg, L., Quinton, J. N., Six, J., and Van Oost, K.: The interdisciplinary nature of SOIL, SOIL, 1, 117-129, doi:10.5194/soil-1-117-2015, 2015.

Cantón, Y., Sole-Benet, A., de Vente, J., Boix-Fayos, C., CalvoCases, A., Asensio, C., and Puigdefábregas, J.: A review of runoff generation and soil erosion across scales in semiarid south-eastern Spain, J. Arid Environ., 75, 1254-1261, doi:10.1016/j.jaridenv.2011.03.004, 2011.

Cerdà, A., Hooke, J., Romero-Diaz, A., Montanarella, L., and Lavee, H.: Preface. Soil erosion on Mediterranean typeecosystems, Land Degrad. Dev., 21, 71-74, doi:10.1002/ldr.968, 2010.

Colazo, J. C. and Buschiazzo, D. E.: Soil dry aggregate stability and wind erodible fraction in a semiarid environment of Argentina, Geoderma, 159, 228-236, doi:10.1016/j.geoderma.2010.07.016, 2010.

Colazo, J. C. and Buschiazzo, D. E.: The Impact of Agriculture on Soil Texture Due to Wind Erosion, Land Degrad. Dev., 26, 6270, doi:10.1002/ldr.2297, 2015.

FAO: Guidelines for soil description, Fourth Edn., Food and Agriculture Organization of the United Nations, Rome, 2006.

Feras, Y., Erpul, G., Bogman, P., Cornelis, W. M., and Gabriels, D.: Determination of efficiency of Vasaline slide and Wilson and Cook sediment traps by wind tunnel experiments, Environ. Geol., 55, 741-757, 2008.

Fister, W. and Ries, J. B.: Wind erosion in the central Ebro Basin under changing land use management. Field experiments with a portable wind tunnel, J. Arid Environ., 73, 996-1004, doi:10.1016/j.jaridenv.2009.05.006, 2009.

Fryrear, D. W., Krammes, C. A., Williamson, D. L., and Zobeck, T. M.: Computing the wind erodible fraction of soils, J. Soil Water Conserv., 49, 183-188, 1994.

Gao, Y., Dang, X., Yu, Y., Li, Y., Liu, Y., and Wang, J.: Effects of Tillage Methods on Soil Carbon and Wind Erosion, Land Degrad. Dev., 27, 583-591, doi:10.1002/ldr.2404, 2015.
Gomesa, L., Arrúe, J. L., López, M. V., Sterk, G., Richard, D., Gracia, R., Sabre, M., Gaudichet, A., and Frangi, J. P.: Wind erosion in a semiarid agricultural area of Spain: the WELSONS project, Catena, 52, 235-256, doi:10.1016/S03418162(03)00016-X, 2003.

Gómez, J. A., Infante-Amate, J., González de Molina, M., Vanwalleghem, T., Taguas, E. V., and Lorite, I.: Olive Cultivation, its Impact on Soil Erosion and its Progression into Yield Impacts in Southern Spain in the Past as a Key to a Future of Increasing Climate Uncertainty, Agriculture, 4, 170-198, 2014.

Hagen, L. J., van Pelt, S., and Sharratt, B.: Estimating the saltation and suspension components from field wind erosion, Aeolian Research, 1, 147-153, doi:10.1016/j.aeolia.2009.08.002, 2010.

Hevia, G. G., Mendéz, M. J., and Buschiazzo, D. E.: Tillage affects soil aggregation parameters linked with wind erosion, Geoderma, 140, 90-96, doi:10.1016/j.geoderma.2007.03.001, 2007.

Houyou, Z., Bielders, C. L., Benhorma, H. A., Dellal, A., and Boutemdjet, A.: Evidence of strong land degradation by wind erosion as a result of rainfed cropping in the algerian steppe: A case study at laghouat, Land Degrad. Dev., doi:10.1002/ldr.2295, online first, 2014.

IBM Corp.: IBM SPSS Statistics for Windows, Version 20.0, IBM Corp., Armonk, NY, 2011.

IUSS Working Group WRB: World Reference Base for Soil Resources 2014, International soil classification system for naming soils and creating legends for soil maps, World Soil Resources Reports No. 106, Food and Agriculture Organization of the United Nations, Rome, 2015.

Kaiser, M., Piegholdt, C., Andruschkewitsch, R., Linsler, D., Koch, H.-J., and Ludwig, B.: Impact of tillage intensity on carbon and nitrogen pools in surface and sub-surface soils of three long-term field experiments, Eur. J. Soil Sci., 65, 499-509, doi:10.1111/ejss.12146, 2014.

Keesstra, S. D., Geissen, V., van Schaik, L., Mosse, K., and Piiranen, S.: Soil as a filter for groundwater quality, Current Opinions in Environmental Sustainability, 4, 507-516, doi:10.1016/j.cosust.2012.10.007, 2012.

Leenders, J. K., Sterk, G., and Van Boxel, J. H.: Modelling windblown sediment transport around single vegetation elements, Earth Surf. Proc. Land., 36, 1218-1229, doi:10.1002/esp.2147, 2011.

Leys, J. F.: Erosion by Wind, Effects on Soil Quality and Productivity, in: Encyclopedia of Soil Science, edited by: Lal, R. and Dekker, M., New York, 499-502, 2002.

Li, F. R., Zhao, L. Y., and Zhang, T. H.: Wind erosion and airborne dust deposition in farmland during spring in the Horqin Sandy Land of eastern Inner Mongolia, China, Soil Till. Res., 75, 121130, doi:10.1016/j.still.2003.08.001, 2004.

Liu, L. Y., Shi, P. J., Zou, X. Y., Gao, S. Y., Yan, P., Li, X. Y., Dong, Z. B., and Wang, J. H.: Short-term dynamic of wind erosion of three newly cultivated grassland soils in Northern China, Geoderma, 115, 55-64, doi:10.1016/S0016-7061(03)00075-2, 2003.

López, M. V., Gracia, R., and Arrue, J. L.: Effects of reduced tillage on soil surface properties affecting wind erosion in semiarid fallow lands of Central Aragon, Eur. J. Agron., 12, 191-199, doi:10.1016/S1161-0301(00)00046-0, 2000.

López, M. V., de Dios Herrero, J. M., Hevia, G. G., Gracia, R., and Buschiazzo, D. E.: Determination of the wind-erodible fraction 
of soils using different methodologies, Geoderma, 139, 407-411, doi:10.1016/j.geoderma.2007.03.006, 2007.

Lozano, F. J., Soriano, M., Martínez, S., and Asensio, C.: The influence of blowing soil trapped by shrubs on fertility in Tabernas district (SE Spain), Land Degrad. Dev., 24, 575-581, doi:10.1002/ldr.2186, 2013.

Martínez-Graña, A. M., Goy, J. L., and Zazo, C.: Cartographic Procedure for the Analysis of Aeolian Erosion Hazard in Natural Parks (Central System, Spain), Land Degrad. Dev., 26, 110-117, doi:10.1002/ldr.2189, 2015.

Novara, A., Gristina, L., Saladino, S. S., Santoro, A., and Cerdà, A.: Soil erosion assessment on tillage and alternative soil managements in a Sicilian vineyard, Soil Till. Res., 117, 140-147, doi:10.1016/j.still.2011.09.007, 2011.

Panagos, P., Van Liedekerke, M., Jones, A., and Montanarella, L.: European Soil Data Centre: Response to European policy support and public data requirements, Land Use Policy, 29, 329-338, doi:10.1016/j.landusepol.2011.07.003, 2012.

Panagos, P., Meusburger, K., Van Liedekerke, M., Alewell, C., Hiederer, R., and Montanarella, L.: Assessing soil erosion in Europe based on data collected through a European network, Soil Sci. Plant Nutr., 60, 15-29, doi:10.1080/00380768.2013.835701, 2014.

Prosdocimi, M., Cerdà, A., and Tarolli, P.: Soil water erosion on Mediterranean vineyards: A review, Catena, 141, 1-21, 2016.

Rawlins, B. G., Turner, G., Wragg, J., McLachlan, P., and Lark, R. M.: An improved method for measurement of soil aggregate stability using laser granulometry applied at regional scale, Eur. J. Soil Sci., 66, 604-614, doi:10.1111/ejss.12250, 2015.

Rodríguez-Caballero, E., Cantón, Y., Chamizo, S., Afana, A., and Solé-Benet, A.: Effects of biological soil crusts on surface roughness and implications for runoff and erosion, Geomorphology, 145, 81-89, doi:10.1016/j.geomorph.2011.12.042, 2012.

Smith, P., Cotrufo, M. F., Rumpel, C., Paustian, K., Kuikman, P. J., Elliott, J. A., McDowell, R., Griffiths, R. I., Asakawa, S., Bustamante, M., House, J. I., Sobocká, J., Harper, R., Pan, G., West, P. C., Gerber, J. S., Clark, J. M., Adhya, T., Scholes, R. J., and Scholes, M. C.: Biogeochemical cycles and biodiversity as key drivers of ecosystem services provided by soils, SOIL, 1, 665685, doi:10.5194/soil-1-665-2015, 2015.
Touré, A. A., Rajot, J. L., Garba, Z., Marticorena, B., Petit, C., and Sebag, D.: Impact of very low crop residues cover on wind erosion in the Sahel, Catena, 85, 205-214, doi:10.1016/j.catena.2011.01.002, 2011.

Udo, K. and Takewaka, S.: Experimental study of blown sand in a vegetated area, J. Coastal Res., 23, 1175-1182, doi:10.2112/050499.1, 2007.

Wang, T., Xue, X., Zhou, L., and Guo, J.: Combating Aeolian Desertification in Northern China, Land Degrad. Dev., 26, 118-132, doi:10.1002/ldr.2190, 2015.

Youssef, F., Visser, S. M., Karssenberg, D., Erpul, G., Cornelis, W. M., Gabriels, D., and Poortinga, A.: The effect of vegetation patterns on wind-blown mass transport at the regional scale: A wind tunnel experiment, Geomorphology, 159, 178188, doi:10.1016/j.geomorph.2012.03.023, 2012.

Zhang, K., Qu, J., Han, Q., Xie, S., Kai, K., Niu, Q., and An, Z.: Wind tunnel simulation of windblown sand along China's Qinghai-Tibet railway, Land Degrad. Dev., 25, 244-250, doi:10.1002/ldr.2137, 2014.

Zhao, H. L., Zhou, R. L., and Drake, S.: Effects of aeolian deposition on soil properties and crop growth in sandy soils of northern China, Geoderma, 142, 342-348, doi:10.1016/j.geoderma.2007.09.005, 2007.

Zhao, H. L., He, Y. H., Zhou, R. L., Su, Y. Z., Li, Y. Q., and Drake, S.: Effects of desertification on soil organic $\mathrm{C}$ and $\mathrm{N}$ content in sandy farmland and grassland of Inner Mongolia, Catena, 77, 187-191, doi:10.1016/j.catena.2008.12.007, 2009.

Zobeck, T. M., Baddock, M., van Pelt, R. S., Tatarko, J., and Acosta-Martinez, V.: Soil property effects on wind erosion of organic soils, Aeolian Research, 10, 43-51, doi:10.1016/j.aeolia.2012.10.005, 2013. 